\title{
ВІДТВОРЮВАЛЬНІ ФУНКЦІІІ СВИНОМАТОК РІЗНИХ ГЕНОТИПІВ ТА ЇХ НАЩАДКІВ
}

\author{
Волощук Василь Михайлович \\ доктор сільськогосподарських наук, член-кор. НААНУ \\ Інститут свинарства і агропромислового виробництва НААНУ \\ ORCID: 0000-0001-6980-1293 \\ Email: pigbreeding@ukr.net \\ Гук Мальвіна Сергї̈вна \\ аспірант \\ Інститут свинарства і агропромислового виробництва НААНУ \\ ORCID: 0000-0002-6593-7596 \\ Email:malvinahuk@ukr.net
}

\begin{abstract}
Запровадження нових технологій виробництва свинини у більшості господарств пов'язано із значною кількостю стресів та розвитку імунодифіцитних станів молодняка. При виникненню стресу відбувається напруження всіх систем організму. Тому дуже важливим при вирощуванні свиней $\varepsilon$ вираховування здатності адаптуватися в умовах технологічних стресів. Для вирішення поставлених завдань вивчали репродуктивну здатність свиноматок, визначали власну продуктивність отриманих нащадків від свиноматок різних генотипів, визначали стійкість до стресу методом «формалінової плями», проводили етологічні дослідження та визначали гематологічні та біохімічні показники крові кнурів. Було встановлено, що за показником маси гнізда у 28 днів переважали свині другої дослідної групи над контрольною та першою дослідними групами, відповідно, 7,6 та 11,4 к己 (р<0,05). За показниками власної продуктивності свинок, а саме за віком досягнення живої маси переважала перша дослідна група над контрольною групою на 5 діб. Середньодобові прирости теж були вищими у свинок першої дослідної групи та переважали контрольну і другу дослідну групи на 4,71 \% та 2,75 \% відповідно (p<0,01). Аналогічно і при визначенні живої маси кнуриів переважала перша дослідна група над контрольною та другою дослідними групами за віком досягнення живої маси 100 кг на 4 та 2 дні відповідно, а також кнуриі першої дослідної групи мали вищі середньодобові прирости на 2,6 \% та 1,2 \% аніж у аналогів. При визначенні адаптаційних особливостей кнуриів методом «формалінової плями» було встановлено найменшу кількість стресчутливих кнуриів у першій дослідній групі (4\%), аніж у контрольній та другій дослідній групах відповідно на 4 та $8 \%$. За етологічними показниками було встановлено, що кнуриі другої дослідної групи мали нижчі показники проявів активної поведінки (на 2,2 \% та 4 \%.) та переважали за показниками сну та відпочинку на 16,7 \% та 8,7 \%. Показники за поїдання корму були нижчі на 22, 15 \% та 22,7 \% аніж у їх ровесників.
\end{abstract}

Ключові слова: свині, кнуриі, продуктивність, адаптація, стрес, етологія.

DOI: https://doi.org/10.32845/bsnau.lvst.2020.1.7

Розробка фізіологічно обгрунтованої системи утримання, годівлі та експлуатації сільськогосподарських тварин в умовах промислових комплексів не можлива без урахування таких категорій, як гомеостаз, стрес і адаптація. Ці питання стали особливо актуальними в останні роки, коли технології ведення свинарства змінюються так швидко, що виникає невідповідність між біологічною природою, фізіологічними можливостями організму і умовами зовнішнього середовища $[1,2]$. Тому досі не вдається домогтися у свиней максимального прояву генетичного потенціалу їхньої продуктивності, реалізація якого, в першу чергу, залежить від відповідності генотипу тварин зовнішньому середовищу, яке найбільш об'єктивно характеризують показники експлуатаційної цінності та адаптаційної здатності свиней $[3,4]$.

Запровадження сучасних технологій виробництва свинини у більшості господарств пов'язано з виникненням значної кількості стресів, які супроводжують від самого народження до забою $[5,6]$.

Особливу увагу слід приділяти свиням при постановці на відгодівлю та відлученні, оскільки в даний період стресові фактори відіграють головну негативну роль у сучасній технології. Ці фактори включають, але не обмежуються самим відлученням, відсутність материнського молока, втрату материнського зв'язку, змішування різних

підстилок, транспортування до вирощувальних та закінчуючих господарств, а також спосіб утримання [7]. У процесі вирощуванні тварин обов'язково слід враховувати здатність тварин до адаптації в умовах технологічних стресів. Тому перед науковцями стоїть завдання щодо способів зниження впливу негативних фракторів навколишнього середовища на організм свиней $[8,9]$.

Продуктивність свиней залежить від багатьох чинників, проте одним із найважливіших є умови утримання, відповідність генотипу яким найбільш об'єктивно характеризує показники відтворювальної та адаптаційної здатності $[10,11,12,13]$. Враховуючи те, що постійно змінюються технології утримання, годівля, змінюється потужність виробництва свиням слід швидко пристосовуватися до змін, а це характерно не всім породним особливостям [14].

Виробництво високоякісної продукції свинарства, а також її збільшення конкуретноспроможності потребує не тільки вдосконалення технологічних аспектів, а й покращенню рішень стосовно відтворення поголів'я, утримання, годівля, раціональне використання породних особливостей, пристосованості свиней до впливу стресфакторів [15].

Матеріали та методи досліджень. Дослідження проводили в умовах ДП «ДГ «Степне» Полтавської області, 
с. Степне та лабораторіях Інституту свинарства і АПВ НААН. Для проведення дослідження було сформовано три групи свиней: контрольна - велика біла+велика біла; дослідна 1 велика біла+миргородська; дослідна 2 - велика біла+миргородська×1/8п'єтрен.

Для вирішення поставлених завдань було визначено відтворювальну здатність свиноматок, проведена оцінка кнурців та свинок за власною продуктивністю, визначено стрес чутливість кнурців методом «формалінової плями», проведені етологічні дослідження та визначені біохімічні та гематологічні показники крові кнурців.

Відтворювальну здатність свиноматок визначали за показниками: багатоплідність (гол.), великоплідність (кг), молочність (кг), маса гнізда у 28 днів (кг), збереженість приплоду (\%).

Оцінку кнурців та свинок за власною продуктивністю визначали за показниками живої маси в 2, 4, 6 місяців, довжиною тулуба в 6 місяців, віком досягнення живої маси
100 кг та середньодобовим приростом.

Дослідження стресстійкості кнурців визначали методом «формалінової плями», суть якого полягає в підшкірному введенні 40\% розчину формаліну в вушну раковину безін'єкторним приладом, та фріксації імунологічних реакції через 24 год., з виявленням змін в області ін'єкції (почервоніння, припухлості).

Етологічні дослідження були проведені за методикою В.І.Велікжаніна (1995 p.), шляхом візуального спостереження упродовж 24 год. Отримані результати вели згідно протоколу. Фіксували різні поведінкові акти: активна поведінка (рух), прийом корму, відпочинок (соH), кількість бійок. Було визначено індекс агресивності.

Результати досліджень. Основними показниками відтворювальної здатності свиноматок $€$ багатоплідність, молочність, маса гнізда в 28 днів, збереженість поросят до відлучення (табл. 1).

Відтворювальна здатність свиноматок, $\bar{x} \pm s_{\bar{x}} \quad(\mathbf{n = 1 0})$

\begin{tabular}{|l|c|c|c|}
\hline \multicolumn{1}{|c|}{ Показник } & \multicolumn{3}{c|}{ Група } \\
\cline { 2 - 4 } & Контрольна & Дослідна 1 & Дослідна 2 \\
\hline Багатоплідність, голів & $11,5 \pm 0,50$ & $9,9 \pm 0,38$ & $10,7 \pm 0,40$ \\
\hline Великоплідність, кг & $1,38 \pm 0,025$ & $1,41 \pm 0,032$ & $1,43 \pm 0,021$ \\
\hline Молочність, кг & $75,00 \pm 1,55$ & $74,60 \pm 0,81$ & $70,34 \pm 1,08$ \\
\hline Маса гнізда у 28 днів, кг & $164,4 \pm 9,29$ & $160,6 \pm 7,99$ & $172,0 \pm 5,72^{*}$ \\
\hline Збереженість поросят до відлучення, \% & $90,88 \pm 2,29$ & $94,95 \pm 3,32^{*}$ & $90,1 \pm 2,75$ \\
\hline
\end{tabular}

Примітка: ${ }^{*} p<0,05$.

Було встановлено, що за показниками багатоплідності перша та друга дослідні групи мали менші показники аніж контрольна відповідно на 1,6 та 0,8 гол., але достовірність не встановлена. За показниками великоплідності та молочності істотних відмінностей не виявлено.

Маса гнізда була вищою у свиноматок другої дослідної групи аніж у контрольній та першій дослідній групах, відповідно на 7,6 та 11,4 кг (р<0,05).
За показником збереженості переважали тварини першої дослідної групи над контрольною та другою дослідною групами відповідно на 4,07 та 4,85\%, що підтверджується достовірністю $(p<0,05)$.

Ріст і розвиток свиней $є$ одним із показників, який відображає взаємодії організму 3 конкретними умовами утримання та його пристосованість до них. Саме тому нами був досліджений приріст живої маси свинок та кнурців (табл. 2).

Таблиця 2

Результати оцінки свинок різних генотипів за власною продуктивністю, ${ }^{\bar{X}} \pm S_{\bar{X}}$ (n=30)

\begin{tabular}{|l|c|c|c|}
\hline \multicolumn{1}{|c|}{ Показник } & \multicolumn{3}{|c|}{ Дослідні групи } \\
\cline { 2 - 4 } & Контрольна & Дослідна 1 & Дослідна 2 \\
\hline Жива маса, 2 міс., кг & $26,9 \pm 1,87$ & $27,9 \pm 0,84$ & $27,6 \pm 1,58$ \\
\hline Жива маса, 4 міс., кг & $65,9 \pm 3,04$ & $69,4 \pm 3,11^{*}$ & $68,8 \pm 3,34$ \\
\hline Жива маса, 6 міс., кг & $113,9 \pm 7,85$ & $118,4 \pm 2,44^{* *}$ & $116,7 \pm 6.35$ \\
\hline Вік досягнення живої маси 100 кг, діб & $162,6 \pm 5,43$ & $157,6 \pm 1,76^{*}$ & $158,9 \pm 2,90$ \\
\hline Середньодобовий приріст, г & $615,0 \pm 10,45$ & $634,5 \pm 10,21^{*}$ & $629,3 \pm 11,98$ \\
\hline
\end{tabular}

Примітка: * $p<0,05 ;{ }^{* *} p<0,01$.

При визначенні живої ваги свинок в 4 місяці було встановлено, що перша дослідна група мала вищі показники аніж контрольна група на 3,5 кг (р<0,05). В 6 місяному віці при контрольному зважуванні переважала перша дослідна група над контрольною на 4,5 кг $(p<0,01)$. За віков досягнення живої маси 100 кг переважали свинки першої дослідної групи над аналогами контрольної групи на 5 та діб (р<0,05). Відповідно за отриманими результатами було встановлено вищий показник середньодобового приросту у свинок першої дослідної групи.

Аналогічно проводили контрольне зважування кнурців в 2, 4, та 6 місяців та розраховували вік досягнення живої маси 100 кг і середньодобовий приріст, також було визначено довжину тулуба в 6 місяців (табл. 3).

Результати оцінки ремонтних кнурців різних генотипів за власною продуктивністю, $\bar{x} \pm s_{\bar{x}}(\mathrm{n}=10)$

\begin{tabular}{|l|c|c|c|}
\hline \multicolumn{1}{|c|}{ Показник } & \multicolumn{3}{|c|}{ Дослідні групи } \\
\cline { 2 - 4 } & Контрольна & Дослідна 1 & Дослідна 2 \\
\hline Жива маса, 2 міс., кг & $26,8 \pm 1,85$ & $27,7 \pm 1,67$ & $26,2 \pm 1,21$ \\
\hline Жива маса, 4 міс., кг & $66,7 \pm 3,73$ & $68,3 \pm 2,07$ & $67,3 \pm 3,01$ \\
\hline Жива маса, 6 міс., кг & $117,3 \pm 6,79$ & $122,3 \pm 5,79$ & $119,3 \pm 6,12$ \\
\hline
\end{tabular}




\begin{tabular}{|l|c|c|}
\hline Довжина тулубу в 6 міс., см & $114,4 \pm 0,47$ & $111,5 \pm 0,34$ \\
\hline Вік досягнення живої маси 100 кг, діб & $159,4 \pm 2,96$ & $155,2 \pm 1,29^{*}$ \\
\hline Середньодобовий приріст, г & $627,4 \pm 11,35$ & $113,6 \pm 0,83$ \\
\hline
\end{tabular}

Примітка: * $p<0,05 ;{ }^{* *} p<0,01$.

Було встановлено, що показниками живої маси від 2 місяців до 6 місяців переважала перша дослідна група кнурців над контрольною та другою дослідними групами. Відповідно і за показниками віку досягнення живої маси переважала перша дослідна група над контрольною та другою дослідними групами на 4 та 2 дні $(p<0,05)$. Середньодобові прирости теж були більшими в кнурців першої дослідніої групи та переважали своїх аналогів на $2,64 \%$ та $1,2 \%$ відповідно ( $p<0,01)$.
Різниця за показником довжини тулуба між кнурцями різних генотипів була незначною і статистично недостовірною.

Для об'єктивної оцінки кнурців про динаміку, характерних поведінкових реакцій організму, провели візуальні спостереження за тваринами протягом 2 суміжних діб, фіксуючи при цьому всі життєві прояви поголів'я (табл. 3 ).

Етологічні показники, Xв (n=10)

\begin{tabular}{|l|c|c|c|}
\hline \multirow{2}{*}{ Етологічні показники } & \multicolumn{3}{|c|}{ Група } \\
\cline { 2 - 4 } & Контрольна & Дослідна 1 & Дослідна 2 \\
\hline Активна поведінка & 494 & 483 & 475 \\
\hline Відпочинок & 284 & 297 & 317 \\
\hline Сон & 204 & 219 & 238 \\
\hline Споживання корму & 319 & 327 & 287 \\
\hline Бійки & 139 & 114 & 123 \\
\hline
\end{tabular}

За даними показниками кнурці котрольної групи переважали над першою та другою дослідної групи за показниками активності на 2,2 \% та 4 \%. За показниками відпочинку перевеважала друга дослідна група над контрольною та першою дослідними групами на $11,6 \%$ та 6,8 \% відповідно. Аналогічно і за показниками сну переважала друга дослідна група над контрольною та першою дослідними групами на 16,7 \% та 8,7 \%.

На поїдання корму найбільша кількість часу була встановлена в першій та другій дослідній групах, 22,15\% та $22,7 \%$ часу.
При виявленні ієрархічних відносин, найбільш активною була контрольна група по відношенню до першої та другої дослідної відповідно на $22 \%$ та 13,9\%. Отже можемо зробити висновок, що в кнурців контрольної групи, при постановці на відгодівлю проявляється пригнічений стан після перегрупуванні.

Для визначення адаптаційних особливостей кнурців методом «формалінової плями» дослідження проводили в період відлучення. Формалін вводили безін'єкційним шприцем, та проводили огляд місця ін'єкції через 24 години (табл.4).

Таблиия 4

Результати дослідження стресчутливості кнурців методом «формалінової плями» $(\mathrm{n}=20)$

\begin{tabular}{|c|c|c|c|c|c|c|c|}
\hline \multirow{2}{*}{ Розподіл за реакцією на стрес } & \multirow{2}{*}{$\begin{array}{c}\text { Розмір формалінової плями, } \\
\text { мм }\end{array}$} & \multicolumn{2}{|c|}{ Контрольна } & \multicolumn{2}{|c|}{ Дослідна 1} & \multicolumn{2}{|c|}{ Дослідна 2} \\
\hline & & Голів & $\%$ & Голів & $\%$ & голів & $\%$ \\
\hline Стресстійкі & від 0 до 21 мм & 18 & 72 & 19 & 76 & 18 & 72 \\
\hline Стресневизначені & $21-30 \mathrm{MM}$ & 5 & 20 & 5 & 20 & 4 & 16 \\
\hline Стресчутливі & 30мм і більше & 2 & 8 & 1 & 4 & 3 & 12 \\
\hline Всього: & & 25 & 100 & 25 & 100 & 25 & 100 \\
\hline
\end{tabular}

За результатами встановлено, що найбільше стресочутливих кнурців, при відлученні, було виявлено в другій дослідній групі (12\%). Після підшкірного введення формаліну було виявлено припухлість і блідо-жовту пляму 3 червоними краями, в діаметрі від 30 мм, що свідчило про їх стресреакцію. Найменша кількість стресчутливих кнурців була виявлена у першій дослідній групі (4\%), аніж у контрольній та другій дослідній групах відповідно на 4 та 8 $\%$.
Стресстійких тварин було виявлено найбільше в першій дослідній групі (76 \%), що на 4 \% більше аніж в контрольній групі.

Під впливом технологічних фракторів змінюється діяльність всього організму, в тому числі і залоз внутрішньої секреції, що викликає зміни в перебігу метаболізму, обміну речовин в організмі в цілому. Одним із показників, які характеризують всі зміни в процесах організму $є$ кров.

Таблиця 5

Біохімічні та гематологічні показники крові кнурців різних генотипів $\bar{X} \pm S_{\bar{X}}$ (n=5)

\begin{tabular}{|l|c|c|c|}
\hline \multicolumn{1}{|c|}{ Показник } & Контрольна & Дослідна 1 & Дослідна 2 \\
\hline Загальний білок, г/л & $73,3 \pm 3,39$ & $70,4 \pm 3,17^{*}$ & $79,7 \pm 3,89^{* *}$ \\
\hline Глюкоза, ммоль/л & $4,2 \pm 0,82$ & $4,4 \pm 0,57$ & $5,4 \pm 0,62$ \\
\hline Креатинін, мкмоль/л & $140,2 \pm 13,77$ & $159,2 \pm 17,23^{* *}$ & $147,3 \pm 12,76$ \\
\hline Кальцій, ммоль/л & $3,1 \pm 0,27$ & $3,1 \pm 0,25$ & $2,9 \pm 0,85$ \\
\hline Фосфор, ммоль/л & $2,2 \pm 0,35$ & $1,7 \pm 0,18$ & $2,2 \pm 0,32$ \\
\hline Холестерин, ммоль/л & $2,4 \pm 0,32$ & $2,8 \pm 0,75^{*}$ & $2,6 \pm 0,26$ \\
\hline Ліпіди, г/л & $3,5 \pm 0,46$ & $3,9 \pm 0,43$ & $3,4 \pm 0,39$ \\
\hline АсАТ, од/л & $76,3 \pm 21,3$ & $71,8 \pm 20,34^{*}$ & $79,3 \pm 19,73$ \\
\hline
\end{tabular}




\begin{tabular}{|l|c|c|c|}
\hline АлАТ, од/л & $57,8 \pm 3,41$ & $56,7 \pm 2,87$ & $56,9 \pm 3,87$ \\
\hline
\end{tabular}

Примітка: * $p<0,05 ;{ }^{* *} p<0,01$.

Отримані результати за загальним вмістом білка у плазмі крові дослідних кнурців свідчить про перебіг обмінних процесів в організмі. За даним показником переважали кнурці другої дослідної групи над контрольною та першою дослідною групами на 8,7 \% та 13,3 \%. Високий вміст білку в крові кнурців другої дослідної групи $€$ характерним для тварин 3 м'ясним напрямом продуктивності, високу інтенсивність росту в даний період.

Рівень глюкози знаходився у межах норми в крові тварин усіх піддослідних груп, проте у стресчутливих тварин вона була дещо меншою, в порівнянні з стресстійкими. Було встановлено, що в кнурців другої дослідної групи показники глюкози були вищими ніж у контрольній та першій дослідній групах на 29,7 \% та 24,3 \% відповідно, що вказує на інтенсивне використання глюкози для забезпечення підвищеного рівня метаболічних процесів та розвитку стадії резистентності стресу, виснаження депонованого глікогену.

Показники креатиніну були у межах норми у всіх дослідних тварин, що свідчить про відсутність порушення ниркової фільтрації.

Встановлено, що концентрація кальцію та фосфрору у крові дослідних кнурців була майже однаковою, в межах норми (кальцій - 2,4-3,2 ммоль/л, фоссрор - 1,4-2,3 ммоль/л). Дані результати можуть свідчити про відсутність характерних змін з боку кальцій-фоссрорного метаболізму.

Ліпіди допомагають у рості організму тварин, а при завершенні росту відкладаються в жирові депо. Таким чином у кнурців контрольної та другої дослідної групах мають найнижчі показники вмісту ліпідів, це свідчить про розвиток м'язової тканини. В першій дослідній групі показник вмісту ліпідів знаходився на рівні майже 4 г/л, що свідчить про розвиток жирової тканини.

Показники холестерину в організмі тварин мають досить велике значення, а також вони пов'язані з ліпідами. Концентрація холестерину в крові значно вища у поросят 3 підвищеною швидкістю росту, ніж у помірної $[16,17]$. Показник холестерину був найбільший у першій дослідній групі, аніж у контрольній та другій дослідних групах на 22,6 $\%$ та $11,7 \%$ відповідно.

Було встановлено, що найвищий показник АсаТ спостерігався у кнурців другої дослідної групи, який переважав над контрольною та першою дослідними групами на $3,91 \%$ та $10,37 \%$. Показник АСаТ $є$ характерним для м'ясних генотипів. 3 віком він може зменшуватися, оскільки починає більше формуватися жирова тканина, що впливає на показники амінотрансферази.

За показником активності АЛаТ у крові можна прослідкувати за стресовим станом тварин, оскільки підвищений АЛаТ свідчать про його посилення в організмі, що призводить до розпаду білків. Також такі зміни вказують на активацію катаболічних та зменшення білок-синтезуючих процесів у їх організмі. Рівень вмісту АлаТ у всіх кнурців дослідних груп знаходився в межах норми.

Висновки: 1. Більшу великоплідність мала друга дослідна група (ВБ $+\mathrm{M} \times 1 / 8 П)$ в порівнянні 3 першою дослідною (ВБ+М) групою. Помісні поросята першої дослідної групи (за участю миргородської породи) характеризувалися вищою збереженістю ніж поросята контрольної групи (ВБ+ВБ) та другої дослідної групи (ВБ $+\mathrm{M} \times 1 / 8 \Pi)$.

2. При визначенні живої маси нащадків (кнурців та свинок) було встановлено, що за показником віку досягнення живої маси 100 кг, середньодобовими приростами переважали помісі кнурці та свинки першої дослідної групи (ВБ +М).

3. При вивченні етологічних особливостей кнурців встановлено, що за показниками активності переважала контрольна (ВБ+ВБ) група над першою $(\mathrm{BБ}+\mathrm{M})$ та другою (ВБ+М×1/8П).дослідними групами відповідно на 2,2 \% та 4 \%. Також при виявленні ієрархічних відносин (бійок), найбільш активною була контрольна (ВБ+ВБ) група по відношенню до першої та другої дослідної відповідно на 22 $\%$ та 13,9 \%, що може свідчити про пригнічені стани кнурців при перегрупуванні.

4. За методом «формалінової плями» було виявлено найбільше стресстійких кнурців в першій дослідній групі (ВБ +М) (76 \%), що на 4 \% більше аніж в контрольній групі. 


\section{Список використаної літератури:}

1. Столюк В., Чумаченко В. Стреси в свинарстві. Пропозиція. [Електронний ресурс]. - Режим доступу: http://propozitsiya.com/ua/stresi-v-svinarstvi (дата звернення 16.08.2012)

2. Решетников А. О., Демчук М. В. Гематологічні дослідження свиней відгодівельних груп з різним коефіцієнтом емоційності. Науковий вісник ЛНУВМБТ імені С.3. Гжицького. 2008. №2 (37). С. 231.

3. Іванов В.О., Волощук В.М. Біологія свиней. Навчальний посібник. Київ: ЗАТ «НІЧЛАВА». 2009. 304 с.

4. Ейдрегевич Е. В., Раевская В. В. Интерьер сельскохозяйственных животных. Москва: Колос. 1978. С. 255.

5. Смирнов В. С. Воспроизводство и адаптация свиней. Свиноводство. 2004. №6. С. 27 - 28.

6. Смирнов В. С. Оценка адаптации свиноматок к интенсивному воспроизводству. Зоотехния. 2003. №7. С. 22 25.

7. Vitaly Bekenev, Arlene Garcia, Vyacheslav Hasnulin, Adaptation of Piglets Using Different Methods of Stress Preventionю Animals (Basel). 2015 Jun; 5(2): 349-360.

8. Толоконцев А. И. Продуктивность свиноматок породы дюрок в ряде поколений при направленой селекции. Свиноводство. 2011. №3. С. $26-28$.

9. Serenius T. K., Stalder T. J., Bass J. W. National pork producers council maternal line national genetic evaluation program: a comparison of sow longevity and trait associations with sow longevity. J. Anim. Sci. 2006. №84. P. 2590-2595.

10. Фридчер А., 2011. Межпородное скрещивание повышает продуктивность. Животноводство России. № 6. С. 31-32.

11. Халак В.І. Адаптація та відтворювальна здатність свиноматок великої білої породи різного походження. Вісник Сумського національного аграрного університету. 2009. № 10. С. 126-130.

12. Церенюк О.М , Хватов А.І., Стрижак Т.А. Ефективність селекційних і оціночних індексів материнської продуктивності свиней. Науково-технічний бюлетень. 2010. № 102. С. 173-181.

13. Ehiobu N. G. Kyado J.A., Njike M.C. Productivity of Large White, Hampshire breeds and their crosses at NAPRI Swine herd, Otukpo, Benue State. Journal of Agriculture Technology \& Education. 2000. №. 5. P. 21-28.

14. William McBride, Nigel Key. Hog Production From 1992 to 2009 : Technology, Restructuring, and Productivity Growth. Economic Research Report No. (ERR-158). 2013. C.8.

15. Лихач В. Я. Обгрунтування, розробка та впровадження інтенсивно-технологічних рішень у свинарстві. Монографія. Миколаїв. 2016. С. 173-174.

16. Heber L. Pork and carcasses quality in swine exploited in family farms. Animal Science and Biotechnologies. 2010. №43 (2). P. 406-408.

17. Агапова Є.М., Решетніченко О.П. Показники крові свиней різних генотипів зв'язок із швидкістю росту. Свинарство. 1996. Вип. 52.

\section{References:} svinarstvi

1. Stoliuk, V., Chumachenko, V. «Stresy v svynarstvi». Propozytsiia. 2011. : URL: http://propozitsiya.com/ua/stresi-v-

2. Reshetnykov, A. O. and Demchuk, M. V., 2008. Hematolohichni doslidzhennia svynei vidhodivelnykh hrup z riznym koefitsiientom emotsiinosti [Hematological studies of pigs in fattening groups with different emotional coefficients]. Naukovyi visnyk LNUVMBT imeni S.Z. Hzhytskoho, no. 2 (37), pp. 231.

3. Ivanov V. O. and Voloshchuk, V. M., 2009. Biolohiia svynei [Biology of pigs]. Navchalnyi posibnyk. Kyiv: ZAT «Nichlava». 304.

4. Eidrehevych, E. V. and Raevskaia, V. V., 1978. Ynterer selskokhoziaistvennыkh zhyvotnыkh [Farm animals interior]. Moskva: Kolos, pp. 255.

5. Smyrnov, V. S., 2004. Vosproyzvodstvo y adaptatsyia svynei [Reproduction and adaptation of pigs]. Svynovodstvo, no. 6, pp. 27-28.

6. Smyrnov, V. S.. 2003. Otsenka adaptatsyy svynomatok $k$ yntensyvnomu vosproyzvodstvu [Assessment of the adaptation of sows to intensive reproduction]. Zootekhnyia, no. 7, pp. 22-25.

7. Vitaly Bekenev, Arlene Garcia and Vyacheslav Hasnulin, 2015. Adaptation of Piglets Using Different Methods of Stress Prevention, Animals (Basel), no. 5(2), pp. 349-360.

8. Tolokontsev, A. Y., 2011. Produktyvnost svynomatok porodb diurok v riade pokolenyi pry napravlenoi selektsyy [Productivity of Duroc sows in a number of generations with targeted breeding]. Svynovodstvo, no. 3, pp. 26-28.

9. Serenius, T. K., Stalder, T. K. Bass J. W., 2006. National pork producers council maternal line national genetic evaluation program: a comparison of sow longevity and trait associations with sow longevity []. Anim. Sci., 84, pp. 2590-2595.

10. Frydcher, A., 2011. Mezhporodnoe skreshchyvanye povbshaet produktyvnost [Crossbreeding increases productivity]. Zhyvotnovodstvo Rossyy, no. 6, pp. 31-32.

11. Khalak, V.I., 2009. Adaptatsiia ta vidtvoriuvalna zdatnist svynomatok velykoi biloi porody riznoho pokhodzhennia [Adaptation and developmental health of sows of the great breeder breed]. Visnyk Sumskoho natsionalnoho ahrarnoho universytetu, no. 10, pp. 126-130.

12. Tsereniuk, O.M, Khvatov, A.I. and Stryzhak, T.A., 2010. Efektyvnist selektsiinykh i otsinochnykh indeksiv materynskoi produktyvnosti svynei [Efficiency of selection and evaluation indices of maternal productivity of pigs]. Naukovo-tekhnichnyi biuleten. Kharkiv, no. 102, pp. 173-181.

13. Ehiobu, N. G. Kyado, J.A. and Njike, M.C., 2000. Productivity of Large White, Hampshire breeds and their crosses at 
NAPRI Swine herd, Otukpo, Benue State. Journal of Agriculture Technology and Education. Vol. 5, pp. 21-28.

14. William McBride, Nigel Key, 2013. Hog Production From 1992 to 2009 : Technology, Restructuring, and Productivity Growth. Economic Research Report, no. (ERR-158). pp. 8

15. Lykhach, V. Ya., 2016. Obhruntuvannia, rozrobka ta vprovadzhennia intensyvno-tekhnolohichnykh rishen u svynarstvi. Monohrafiia. Mykolaiv. pp. 173-174.

16. Heber, L., 2010. Pork and carcasses quality in swine exploited in family farms. Animal Science and Biotechnologies. no. 43 (2). pp. 406-408.

17. Ahapova, Ye.M., Reshetnichenko, O.P., 1996. Pokaznyky krovi svynei riznykh henotypiv zviazok iz shvydkistiu rostu. Svynarstvo. no. 52.

Voloshchuk Vasyl Mykhailovych, doctor of Agricultural Sciences, corresponding Member of NAASU

Huk Malvina Serhiivna, postgraduate student

Institute of Pig Breeding and Agroindustrial Production of NAASU

\section{Reproductive functions of sows of different genotypes and their descendants}

New technologies of pork production in most farms are associated with the emergence of significant amounts of stress and the development of immunodeficient conditions in young animals. When stress occurs, the tension of all body systems. To solve the tasks we studied the reproductive ability of sows, determined the own productivity of domestic and foreign breeding boars, determined the resistance to stress by the method of "formalin spot", conducted ethological studies and determined hematological and biochemical parameters of boars blood is determined. Therefore, it is very important when raising pigs is to calculate the ability to adapt to technological stress. It was found that the nest weight at 28 days was dominated by pigs of the second experimental group over the control and first experimental groups, respectively, 7.6 and $11.4 \mathrm{~kg}(p<0.05)$. According to the indicators of own productivity of pigs, namely for the age of achieving live weight, the first experimental group prevailed over the control group for 5 days. The average daily gains were also higher in the pigs of the first experimental group and prevailed in the control and second experimental groups by $4.71 \%$ and $2.75 \%$, respectively $(p<0.01)$. Similarly, when determining the live weight of boars, the first experimental group prevailed over the control and second experimental groups at the age of $100 \mathrm{~kg}$ at 4 and 2 days, respectively, and boars of the first experimental group had higher average daily gains of $2.6 \%$ and $1.2 \%$ than analogues. When determining the adaptive characteristics of boars by the "formalin spot" method, the lowest number of stresssensitive boars was found in the first experimental group (4\%) than in the control and second experimental groups by 4 and $8 \%$, respectively. According to ethological indicators, it was found that boars of the second experimental group had lower rates of active behavior (by $2.2 \%$ and $4 \%$.) And prevailed in terms of sleep and rest by $16.7 \%$ and $8.7 \%$. Indicators for eating food were lower by $22.15 \%$ and $22.7 \%$ than their peers.

Key words: pigs, boars, productivity, adaptation, stress, ethology.

Дата надходження до редакції: 03.02.2020 p. 